\title{
Hotel Marketing Strategy in Biak Papua to Survive During the Covid- 19 Pandemic
}

\author{
Andi Sahat Maasi Sigalingging1, Dominggus Rudolf Leiwakabessy ${ }^{2}$ \\ Institut Ilmu Sosial dan Ilmu Politik (IISIP) YAPIS Biak \\ Email: andy.sigalingging@gmail.com
}

(Received: January-2021; Reviewed: February-2021; Accepted: March-2021;

Avalaible Online: March-2021; Published: March-2021)

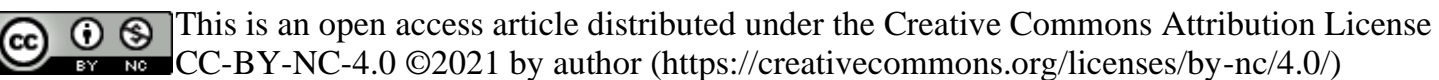

\begin{abstract}
The pandemic has paralyzed global tourism. In Biak Papua, the impact of the pandemic on the tourism industry is enormous. Almost all hotels stop operating, even if one is open, that also opens up for the quarantine of Covid sufferers. This article examines the condition of hotels in Biak and the survival marketing strategies adopted during the outbreak. This research uses a descriptive qualitative approach using in-depth interviews and literature studies on books, scientific journals, and online news. This study focuses on Basana Inn and Manna Inn, on the grounds of the level of representation of the Jasmine Hotel and customer types. The research results show that the impact of the pandemic has resulted in almost empty hotel occupancy. The strategy carried out is almost the same, namely by terminating employees permanently and temporarily, limiting the use of hotel facilities, spending efficiency, selling non-room products online, and refusing to refund bookings by changing visit schedules. During the Covid 19 pandemic, a marketing strategy is very important to do. In obtaining optimal results, strategies in marketing are carried out which have a very broad scope, including analytical strategies to face competition, price strategies, product strategies, service strategies and so on. The Covid 19 outbreak has given service companies a sense of worry or discomfort, especially the Basana Inn Hotel which is engaged in accommodation services. Seeing the results of the identification of problems in this study, researchers are interested in researching the title "Hotel Marketing Strategies in Biak Papua to Survive the Covid-19 Pandemic." The purpose of this research is to find out and analyze the most appropriate strategy in the Covid 19 Pandemic situation.
\end{abstract}

Keywords: Strategy; Hotel Marketing Transparency; Covid-19

\section{INTRODUCTION}

Several countries in the world are currently facing war, namely the war against the virus which is often referred to as covid-19 (Coronavirus Disease 2019). Since the announcement of covid-19 as a global epidemic or pandemic by the World Health Organization (WHO) on March 11, 2020, covid-19 has become very scary for all countries because of its very fast spread. 
Based on the WHO announcement, many countries have finally taken action to prevent the increasing number of victims of Covid-19 from keeping their distance (Social distancing) to locking down (not being allowed to leave their homes at all). Indonesia has taken various policies such as working from home, social distancing, Large-Scale Social Restrictions (PSBB).

Tax revenues also decreased due to weakening economic activity and falling world oil prices. Taxes have a function, namely as a source of funds for the central and regional governments to carry out development. The decline in taxes was also exacerbated by the slowdown in economic activity of the Large-Scale Social Restrictions (PSBB), the provision of stimulus and facilities and the decline in commodity prices. The sector most affected by the coronavirus is tourism. Currently, there are many hotels and restaurants that have temporarily closed their businesses, both from the jasmine class to five-star hotels due to lack of income. Tourist attractions and travel agencies also do the same. Whereas tourism is the largest foreign exchange earner for the country. Like Biak Papua, the main source of revenue for PAD is hotel and restaurant taxes. As a result of the decline in tourism sector income, many layoffs occurred, causing a decrease in people's income and increasing unemployment.

The tourism industry is one of the service providers currently affected by Covid 19 which has hit Indonesia since March 2020. Through Circular Letter Number 2/2020 concerning the continued prevention and spread of the Coronavirus Disease 2019 (COVID-19) outbreak, he appealed to the office in charge of the tourism sector. and the creative economy consult and report on the progress of the implementation of anticipation and handling of the impact of the transmission of COVID-19 in their respective areas of authority on a regular basis. In addition, the relevant agencies need to disseminate the Standard Operating Procedures (SOP) for good business operations and according to the Health Protocol of the Ministry of Health. The health protocol was conveyed through social media, print media, radio, and sending mass messages through whatsapp groups in each region.

Another effort that can be made is the purchase of catering from hotels and restaurants affected by the lack of tourists to be distributed to families who work from home (WFH), underprivileged families, doctors and nurses in hospitals. In addition, it is also expected to take preventive measures by taking preventive measures so that the company does not reduce the workforce and conduct a negotiation with the workforce to discuss the best way for the company and employees.

The relevant government related to tourism and the creative economy (parekraf) should be able to provide the best solution by providing assistance such as basic necessities or other basic needs so that workers affected by COVID-19 can be affected. Where workers in the tourism sector and the creative economy (parekraf) have readiness in dealing with what is happening with their work, such as being laid off for an undetermined time.

In this case, of course, a strategy is needed to overcome it, where this strategy is a comprehensive plan of how a company will achieve its mission and goals. The strategy will maximize competitive advantage and minimize competitive limitations (Wheeleen \& Hungger, 2012) Strategies are formulated to mobilize various organizational resources and direct them to the achievement of the organization's vision. Without the right strategy, the organization's resources will be wasted consumption, so that it will result in the organization's failure to realize its vision. In a competitive business environment, strategy plays an important and decisive role in maintaining the survival and growth of the company.

In this case (Assauri, 2015) suggests that the marketing strategy is a set of goals and objectives, policies and rules that give direction to the company's marketing efforts from time to time, at each level and its references and applications, especially as the company's response to the ever-changing competitive environment and conditions. Marketing strategy is used to carry out marketing activities within a company by looking at competitive conditions and the 
environment in the target market to create value for customers and achieve the desired goals. In an effort to determine the marketing strategy to be implemented, the company must first look at the situation and conditions so that marketing activities can be determined.

Therefore, judging from the hotel's marketing strategy, this hotel is a company managed by the owner by providing food, drink and room facilities for sleeping to people who are traveling and are able to pay a reasonable amount in accordance with the services received without a special agreement. While the understanding published by Grolier Electronic Publishing Inc. (1995) which states that: Hotel is a commercial business that provides a place to stay, food, and other services to the public.

The hospitality industry can also be referred to as a group of companies that provide personal services to consumers who are part of a service company (Morrison, 2002). A service company is any action or action that one party can offer to another that is essentially intangible and does not result in ownership (Kotler, 2010).

\section{METHOD}

In this research is descriptive qualitative, with methods of instrument validity and reliability guidelines and data collection quality regarding the accuracy of the methods used to collect data. Instruments in qualitative research can be in the form of tests, interview guidelines, observation guidelines, and questionnaires.

According to (Maleong, 2005, p. 6) qualitative research is research that intends to understand phenomena about what is experienced by research subjects such as behavior, perception, motivation, action, etc. holistically, and by way of description in the form of words and language. , in a special natural context and by utilizing various natural methods.

Research Informants The determination of research informants is intended so that research can obtain as much information as possible which is considered to know and participate in the process of carrying out the duties and functions of their respective parts, with experience and knowledge they can provide information regarding the data needed in this research. With all the complexities associated with the marketing strategy at Hotel Basana Inn. Internal informants in this study were the leaders and employees of Hotel Basana Inn who were considered to be able to provide information or input data that could be used in writing this research.

Data Collection Techniques Data collection techniques can be done by observation and interview techniques, the author conducts questions and answers and direct discussions with related parties.

\section{RESULT AND DISCUSSION}

\section{Basana Inn Hotel Marketing Strategies}

Each company will enter a target market and market products or services to target market consumers. This marketing is carried out by each company to get the maximum profit in accordance with the efforts made in producing products or services, and to meet the company's own goals. According to (Sudaryono, 2006) Marketing is a combination of interrelated activities to find out consumer needs through the creation, offering and exchange of valuable products and services as well as developing promotions, distribution, services and prices so that consumer needs can be well satisfied at a high level. certain advantages.

Marketing strategy is basically a comprehensive, integrated and unified plan in the field of marketing that provides guidance on the activities to be carried out to achieve the marketing 
objectives of a company. A marketing strategy is needed in every hotel industry such as Hotel Basana Inn which is oriented to the profit function.

Currently the whole world is being hit by the Covid 19 outbreak and it has an impact on all aspects of life. The emergence of the corona virus has made many people afraid to do activities outside the house, especially out of town. They tend to delay or even cancel. The domestic and foreign tourism sectors are all affected and our task is to make efforts not to drop further, and must create anticipation.

The government has also issued regulations to anticipate the spread of Covid 19, by reducing the movement of people. Along with this, every company must anticipate by adjusting to government regulations but must also concentrate on the company's targets.

By implementing an effective marketing strategy through the use of existing opportunities to increase sales, it is expected to maintain and improve the company's position in the market. The implementation of the current marketing strategy is very important to support increased profits. To obtain optimal results, marketing strategies have a broad scope, including strategies to face competition, pricing strategies, product strategies, service strategies and so on. Companies need to recognize the company's strengths and weaknesses in the competition this will be very helpful to identify themselves, and be able to take advantage of every opportunity that exists and avoid or minimize the risks that exist.

For the sake of marketing strategies implemented for effective results in having existing opportunities for increased sales, it is expected to maintain and improve the company's position in the market. The implementation of the current marketing strategy is very important to support increased profits. To obtain optimal results, marketing strategies have a broad scope, including strategies to face competition, pricing strategies, product strategies, service strategies and so on. Companies need to recognize the company's strengths and weaknesses in the competition this will be very helpful to identify themselves, and be able to take advantage of every opportunity that exists and avoid or minimize the risks that exist.

Hotel Basana Inn is a private hotel located in the center of Biak city. In the midst of the Covid-19 pandemic, this three jasmine hotel experienced a decline in occupancy due to social distancing and people were advised not to travel. Currently they are making a strategy on how to continue to earn revenue by not only relying on room occupancy and MICE as follows:

1. Product Strategy

The implementation of the product strategy is to maximize room sales via online, one of which is travel services. In addition to ensuring the cleanliness of the rooms and buildings for the comfort of the guests.

2. Pricing Strategy

The price strategy used is to adjust to the capacity of the local community, Hotel Basana Inn wants to introduce a $65 \%$ reduction in room rates. To guests starting from Rp. 350,000 per night without breakfast, Rp 450,000 with breakfast up to self-isolation package Rp. 4,900,000 for 14 days.

3. Place

Basana Inn's location is very strategic in Biak, close to the airport, port, shopping center (mall) and souvenir market. In this covid pandemic situation, Hotel Basana Inn implemented a strategy to strengthen its position as a hotel with comfort in the downtown area of Biak.

4. Promotion Strategy

The promotions carried out are through social media advertisements and Whatsapp conversation applications with the PO (Purchase Order) mechanism. 


\section{Basana Inn Analisis Hotel Marketing Strategy SWOT Analysis}

In this study, information on internal factors was obtained based on the results of in-depth interviews with the General Manager of the Hotel and the Marketing Team.

\section{Table 1. SWOT Matrix at Hotel Basana Inn}

\begin{tabular}{|c|c|c|}
\hline IFAS/EFAS & $\begin{array}{l}\text { STRENGTHS (S) } \\
\text { - Number of rooms } 40 \text { with } \\
\text { standard Melati } 3 \text {. hotel } \\
\text { - Located in the center of } \\
\text { Biak city, close to one of } \\
\text { the Hadi Supermarket } \\
\text { Malls, the port, Bank } \\
\text { - Have a Meeting Room for } \\
\text { MICE activities } \\
\text { - Wi fi in the hotel area as } \\
\text { well as a large parking lot }\end{array}$ & $\begin{array}{l}\text { WEAKNESSES }(\boldsymbol{W}) \\
\text { - Branding room prices } \\
\text { that seem always } \\
\text { expensive makes } \\
\text { people reluctant to } \\
\text { come. } \\
\text { - An old building that } \\
\text { looks old even though } \\
\text { there have been some } \\
\text { renovations. }\end{array}$ \\
\hline $\begin{array}{l}\text { OPPORTUNITIES }(\mathbf{O}) \\
\text { - Biak as transit guest } \\
\text { destination from Serui } \\
\text { Yapen Waropen } \\
\text { - Decreasing room rates to } \\
\text { attract customers }\end{array}$ & $\begin{array}{l}\text { STRATEGI (SO) } \\
\text { - Word of mouth marketing } \\
\text { - Promotion through social } \\
\text { media and whatsapp chat } \\
\text { applications } \\
\text { - Cooperate with travel } \\
\text { agents for room } \\
\text { promotions } \\
\text { - Making information about } \\
\text { the health protocols carried } \\
\text { out by Hotel Basana Inn to } \\
\text { improve guest comfort }\end{array}$ & $\begin{array}{l}\text { STRATEGI (WO) } \\
\text { Optimizing marketing to } \\
\text { always promote hotel } \\
\text { facilities and room price } \\
\text { promotions }\end{array}$ \\
\hline $\begin{array}{l}\text { THREATS }(\mathbf{T}) \\
\text { Many other hotels offer } \\
\text { cheap rates for rooms. }\end{array}$ & $\begin{array}{l}\text { STRATEGI (ST) } \\
\text { - Give trust to the community } \\
\text { about Basana Inn and its } \\
\text { services. } \\
\text { - Implement health protocols to } \\
\text { make people comfortable } \\
\text { interacting with the Basana } \\
\text { Inn Team. }\end{array}$ & $\begin{array}{l}\text { STRATEGI (WT) } \\
\text { - Added types of room } \\
\text { service. } \\
\text { - Create the concept of an } \\
\text { indoor room complete } \\
\text { with wi fi. } \\
\text { - Carry out renovations to } \\
\text { reduce the impression of } \\
\text { the old Hotel Basana Inn } \\
\text { building. }\end{array}$ \\
\hline
\end{tabular}

1. Strengths owned by Hotel Basana Inn include:

- Hotel Basana Inn has a room capacity of 40 rooms with 3 Melati Hotel standards ranging from standard, deluxe and superior rooms 
Volume 4, Issue 2, March 2021 Page. 319- 326

- Hotel Basana Inn is located in the center of Biak city, with all facilities, Mall, Bank, ATM, culinary center, Fish Market and Port / Airport.

2. Weaknesses (weaknesses)

- Hotel Basana Inn is one of the private hotels that has an expensive impression among the public. This has become one of the weaknesses in marketing during the Covid-19 outbreak. But through a promotion I want to inform you that Basana Inn is actually affordable and still exists in the community to provide the best facilities for guests.

- Old Hotel building that looks old

3. Opportunities

- The biggest opportunity is the city of Biak as the main transit destination for passengers from surrounding regencies, namely Waropen, Serui and Yapen Island

- Standard 3 jasmine hotel rooms are sold at a $65 \%$ price reduction providing an opportunity to attract people to stay. With affordable prices, you can enjoy hotel facilities.

4. Threats (Threats)

- Many other hotels offer cheap rates for rooms

- Based on the SWOT analysis, it can determine the various possibilities that can be taken by Hotel Basana Inn. In this case, the strategies that can be taken in marketing Hotel Basana Inn products include:

- Give trust to the public about Hotel Basana Inn products which include rooms and food

- Stay consistent with health protocols so that people are comfortable interacting with the Basana Inn Team

- Make a concept of room facilities complete with wi fi.

- Renovating to reduce the old impression of the hotel building, the moment when covid 19 can be used as a moment to make changes.

The COVID-19 pandemic that has been going on since the beginning of 2020 has had a negative impact on various industries, including the hotel industry. Indonesia is one of the regions in the world that has been affected by COVID-19. The hospitality industry has experienced a drastic decline in occupancy, therefore it is necessary to implement appropriate and effective strategies in order to stabilize the declining occupancy. The results of the analysis conducted based on the SWOT analysis in improving the hotel's marketing strategy seem to still need development which significantly requires a mature strategy in increasing revenue in the midst of this postpandemic. This pandemic has dealt a blow to the tourism industry in the world, especially in Biak Regency and the hotel sector has also been significantly affected, as many hotel businesses are in danger of going out of business. Therefore, so that this 
does not happen, hoteliers must be able to rise again by providing creations and innovations based on strategies that will be carried out in the future.

The explanation above shows that the ability and quality of human resources is needed in redeveloping the hotel industry in Biak Regency by taking a mature strategic approach so that the impacts that occur during this pandemic can be handled properly. If viewed from the focus on this problem at the Basana Inn Hotel based on the results of the SWOT analysis that the strength it has is located in the city center, so that it is a big advantage because it is able to attract visitors who are outside the area, so it is necessary to approach the community or visitors with hotel marketing strategies that are able to reach out in conveying accurate and good information regarding the advantages of Hotel Basana Inn in order to be able to attract attention, besides that it is necessary to approach students by offering study packages to students or students who are on vacation. When viewed from the weakness of the Basana Inn hotel, many people justify that the hotel seems expensive so that it can reduce the interest of the public or visitors to stay at the Basana Inn Hotel, therefore the most ideal strategy is to promote the hotel by giving an attractive impression. and reduce the impact of the public opinion that seems expensive. Judging from the opportunities that Hotel Basana Inn has, there are flight transits from three regions that can support it, therefore this opportunity must be done to create mature opportunities by giving an attractive impression through a hotel promotion approach strategy with discounts in order to attract visitors to rest. . Besides that, it is necessary to implement a hotel security method that is free from COVID-19 so that the public or visitors do not feel afraid. So seeing the threats that will occur can be minimized and evaluated properly and gradually. However, in this study, it was found a threat that there were many other hotels that offered cheap prices and good facilities, if you look at this, the strategy needed to be better, namely by making improvements to more adequate facilities and infrastructure.

Based on the above, the Basana Inn hotel marketing strategy needs to be carried out with various approaches that are more effective and efficient in order to be able to create good solutions and alternatives with the marketing strategy that will be carried out. Therefore, based on the results of interviews in this study, it can be illustrated that strategic approaches are still needed, such as by taking advantage of the momentum of the COVID-19 pandemic, namely by collaborating with local governments, especially the tourism office, in order to provide hotel marketing promotions with an approach to hotel facilities and facilities that impress attract visitors and the public. Besides that, there needs to be an impression given to students who are on vacation so that they are given the convenience of an affordable price. Therefore, the conclusion that can be drawn is that the marketing strategy of Hotel Basana Inn needs to be carried out based on innovation and human resources owned by taking advantage of the moments that occur and seeing opportunities that will occur, namely by collaborating with the government from all existing fields so that the marketing strategy process can be implemented. running well and effectively. In addition, it is necessary to renovate the hotel which triggers the lack of interest in visiting because it is very important to provide comfort to the community, if this is done well then the opportunities that will occur in the future can run well so that the threats that will occur can be avoided. minimized so that the evaluation process that will be carried out in the future can be 
found the main problem and solution so that in this case it can form effective and efficient decisions in dealing with problems that will occur in the future. Therefore, it needs support from all existing aspects, both from the leadership and hotel employees with adequate quality human resources.

\section{CONCLUSION}

The marketing strategy carried out by Hotel Basana Inn in the Covid-19 Pandemic situation is to utilize human resources and hotel facilities to create and innovate in this situation. Namely the use of hotel facilities for sale to the public. In this situation can not only rely on the room to survive. The strategy used provides great benefits for the existence of Hotel Basana Inn. In this situation, the team learned new lessons and innovations in producing something new to increase hotel revenue. Even though the company's target cannot be met 100\%, at least during the Covid-19 pandemic, the Basana Inn Hotel can contribute to meeting the needs of the people of Biak and its surroundings. For this reason, Basana Inn Hotel is advised to maintain quality and prices to foster loyalty from customers and remain consistent in carrying out health protocols so as to make people comfortable interacting with the Basana Inn Team to make changes and carry out renovations to reduce the impression of old hotel buildings, the moment when Covid 19 can be used as a moment and continue to innovate to contribute to the country and the people of Indonesia.

\section{REFERENCES}

Amstrong, G., \& Kotler, P. (2012). Prinsip-Prinsip Pemasaran (Edisi 12 J). Jakarta: Erlangga. Assauri, S. (2015). Manajemen Pemasaran. Jakarta: PT. Raja Grafindo Persada.

Cravens, D., \& Pieryn, N. (2006). Marketing Strategic (Edition 9). Singapore: c Graw-Hill Companies co.

Gossing, S., Scott, D., \& Hall, M. (2020). Pandemic, tourism and global change: a rapid assessment of COVID-19. Journal of Sustainable Tourism, 29(1), 1-20. https://www.tandfonline.com/doi/full/10.1080/09669582.2020.1758708?scroll=top\&need Access $=$ true

Kotler, P. (2010). Manajemen Pemasaran. Edisi Tiga Belas Bahasa Indonesia, Jilid 1 dan 2. Jakarta: Erlangga.

Maleong, L. J. (2005). Metodologi Penelitian Kualitatif. Bandung: PT Remaja Rosdakarya.

Morrison, A. M. (2002). Hospitality and Travel Marketing (Edisi ke 3). New York: Delmar.

Sudaryono. (2006). Manajemen Pemasaran Teori dan Implementasi. Yogyakarta: ANDI.

Tjiptono, F. (2008). Strategi Pemasaran (Edisi Kedua). Andi.

Wheeleen, T. L., \& Hungger, J. D. (2012). Strategic Management and Business Policy: Toward Global Sustainability (13th Edition). New York: Pearson. 